\title{
Deep geoelectrical investigation to bound a coastal thermal outflow area
}

\author{
Enzo Rizzo $^{1}$, L.E. Zuffianò ${ }^{2}$, F. Santaloia ${ }^{2}$ and M. Polemio ${ }^{2}$ \\ ${ }^{1}$ CNR-IMAA, National Research Council - Institute of Methodology for Environmental \\ Analysis, C.da S. Loja, 85050 Tito Scalo, Italy \\ ${ }^{2}$ CNR-IRPI, National Research Council - Research Institute for Hydrogeological Protection \\ Via Amendola 122 I, 70126 Bari, Italy
}

\begin{abstract}
The coastal carbonate Apulian aquifers, located in southern Italy, feed several coastal fresh springs and constitute the main local source of high quality water. The Santa Cesarea Terme cave system is almost unique case of hypogenic coastal spring caves, located along the Adriatic Sea coastline and hosting spring coastal outflow of mixed groundwater (from $22^{\circ} \mathrm{C}$ to $33^{\circ} \mathrm{C}$ ) mainly of thermal groundwater due to infiltration offshore, in the sea bottom, and pure fresh groundwater due rainfall infiltration.

Thermal springs and the outflow system are strictly controlled by both the discontinuity network and the karst processes involving the foreland environment. Detailed geoelectrical prospecting were carried out to bound the upflow continental area of this system, considering the geoelectrical effects of deep water mixing with different salinity and temperature close the Adriatic coast.
\end{abstract}

\section{INTRODUCTION}

The sulphurous and thermal waters of Santa Cesarea Thermal springs are known from ancient times (e.g. Aristotle in IV century BC). They flow out along a well-defined, $500 \mathrm{~m}$ long, coastal sector of the Salento peninsula, which is part of the Apulia carbonate platform, (i.e. the foreland of the Apennines-Dinarides orogeny; Ricchetti et al. 1988), consisting of Jurassic-Cretaceous limestone and dolostone, over $5 \mathrm{~km}$-thick in the study area. This succession rests above Late Triassic evaporites (Burano Fm), and is unconformably overlain by Cenozoic calcareous successions with stratigraphic lacunae.

The thermal water of Santa Cesarea Terme area origins offshore with the infiltration of fresh seawater, flowing down to several hundreds of meters below the sea level, almost directly into the deeply fractures Apulian carbonate platform (Santaloia et al 2016). The seawater flows downward along steeply inclined faulted zones and interacts with different rocks that are geothermally heated at least at $80-85{ }^{\circ} \mathrm{C}$. Thereafter, this sulphurous water is driven upwards crossing the coastal transition zone of the seawater intrusion by density difference phenomena. Then, it outflows through the coastal springs of the Santa Cesarea Terme system, mixing itself with the continental pure fresh groundwater and the seawater. The whole flow system of thermal water should be considered a convective cell process.

Detailed geoelectrical prospecting were carried out to bound the upflow continental area of this cell, considering the geoelectrical effects of deep water mixing with different salinity and temperature close the Adriatic coast.

\section{METHODS}

In the investigated area, n. 6 high-resolution Electrical Resistivity Tomographies (ERTs) were performed, as shown in Figure 1. 
The ERT method consists in the determination of the apparent resistivity parameter $(\mathrm{Ohm} * \mathrm{~m})$, through combined measurements of electric current intensity, injected in the subsoil by means of a pair of electrodes fixed in the ground, and drop of potential measured on two different electrodes. The acquired data are memorized and subsequently elaborated by ad hoc software, in order to obtain the electrical resistivity distribution. In the last decade, the use of ERT was very intensive for the investigation of complex geological areas (geothermal areas, volcanoes, etc.). In particular, the geoelectrical technique of surface tomography along a profile consists in the realization of an extreme detail image of the areal behavior of the electrical resistivity along the plane of the vertical section passing through the chosen profile. The high resolution obtained by this technique makes it possible to discriminate much more effectively the resistivity contrasts existing in the subsoil, thus providing more reliable information on the subsoil: geological discontinuity (Caputo et al. 2003; Rizzo et al. 2004), groundwater, landslide systems (Lapenna et al. 2003; Perrone et al. 2004), buried archaeological finds (Rizzo et al. 2004).

The instrumentation used was the Syscal R2 with a 48-channel multi-electrode system and an electrode spacing of $20 \mathrm{~m}$. Each profile was long $940 \mathrm{~m}$ and the investigation depth was about $180 \mathrm{~m}$. The used geoelectrical methodology was the Wenner-Schlumberger (WS), which allows to obtain a high $\mathrm{S} / \mathrm{N}$ ratio and good information on vertical structures (i.e. faults) and horizontal layers (i.e. geological stratigraphy). The apparent resistivity data were processed by the RES2DINV software (Loke 2001) to obtain in real time tomographic subsurface images of the electrical resistivity pattern. The 2D inversion routine applies a Gauss-Newton least squares method (Loke and Barker 1996), based on the finite-difference model of the subsurface, automatically adjusted in an iterative process. The Root Mean Squared (RMS) error provides a measurement of the quality of the inversion process.

\section{GEOLOGICAL AND HYDROGEOLOGICAL SETTING}

The Santa Cesarea Terme area is located along the south-eastern coast of the Salento peninsula, a carbonate platform defined by a wide, WNW-ESE trending, antiform structure, dissected by a series of extensional and strike-slip faults (Tozzi 1993).

As shown in the geological map of Figure 1, the Upper Cretaceous Altamura Limestone represents the calcareous bedrock at Santa Cesarea Terme, consisting of well-bedded, peritidal limestone and dolomitic limestone. Locally the Late Eocene-Early Oligocene coral reef limestone, belonging to the Castro Limestone, overlays the Cretaceous formation through a marked angular unconformity (Figure 1; Bosellini et al. 1999; Bossio et al. 2005). Both Altamura Limestone and Castro Limestone are unconformable overlain by the bentonic foraminifer-bearing Oligocene calcarenite (Porto Badisco Calcarenites). The youngest formation cropping out at Santa Cesarea Terme is the Salento Calcarenites (Pleistocene), consisting of massive to poorly bedded, weakly cemented calcarenites, related to a slope environment, as testified by the presence of slumpings and submarine slides. The offshore equivalent of the Salento Calcarenites are well imaged in the seismic lines and form a series of prograding units settled during a forced regression (Aiello and Budillon 2004). In the studied area, groundwater flow within a deep aquifer that occurs within the intensely fissured and karstified Altamura Limestone, Castro Limestone and Porto Badisco Calcarenites (Romanazzi et al. 2015, De Giorgio et al. 2018). These units have the same hydrogeological characteristics and play an important common role in the groundwater circulation. The borehole n. 4 (VIGOR well, Abate et al. 2015) has crossed the rocky succession of the deep aquifer. As shown by the rock coring, this succession is composed primarily of white fine and medium grained micritic limestones ( $\mathrm{L}$ in Figure 1c), locally interbedded with dolomitic limestone and dolomite (L/DL in Figure 1c i.e. 135-145 m, 285-290 m and 295-300 $\mathrm{m}$ below 
the ground level). Biogenic structures, as biostromal rudists ( $\mathrm{rb}$ in Figure 1), have been found between $200 \mathrm{~m}$ and $215 \mathrm{~m}$ below the ground level. Many karst forms (microcavities, karst fractures, calcitic concretions, etc.) have been intercepted even at considerable depths. They seem to decrease starting from $230 \mathrm{~m}$ from the ground level (about $-115 \mathrm{~m}$ a.s.1.). Moreover, it is important to note that the evolution of hypogenic karst forms should have been strongly influenced by the fluctuations of the karstic base level. This level has been linked to the sea-level oscillations occuring during the Quaternary. Morever, in the coastal study area, the development of the karst cavity should have been is also influenced by the fluctuation of the zone of dispersion where the seawater mix with the fresh groundwater (De Waele and Piccinni, 2008).

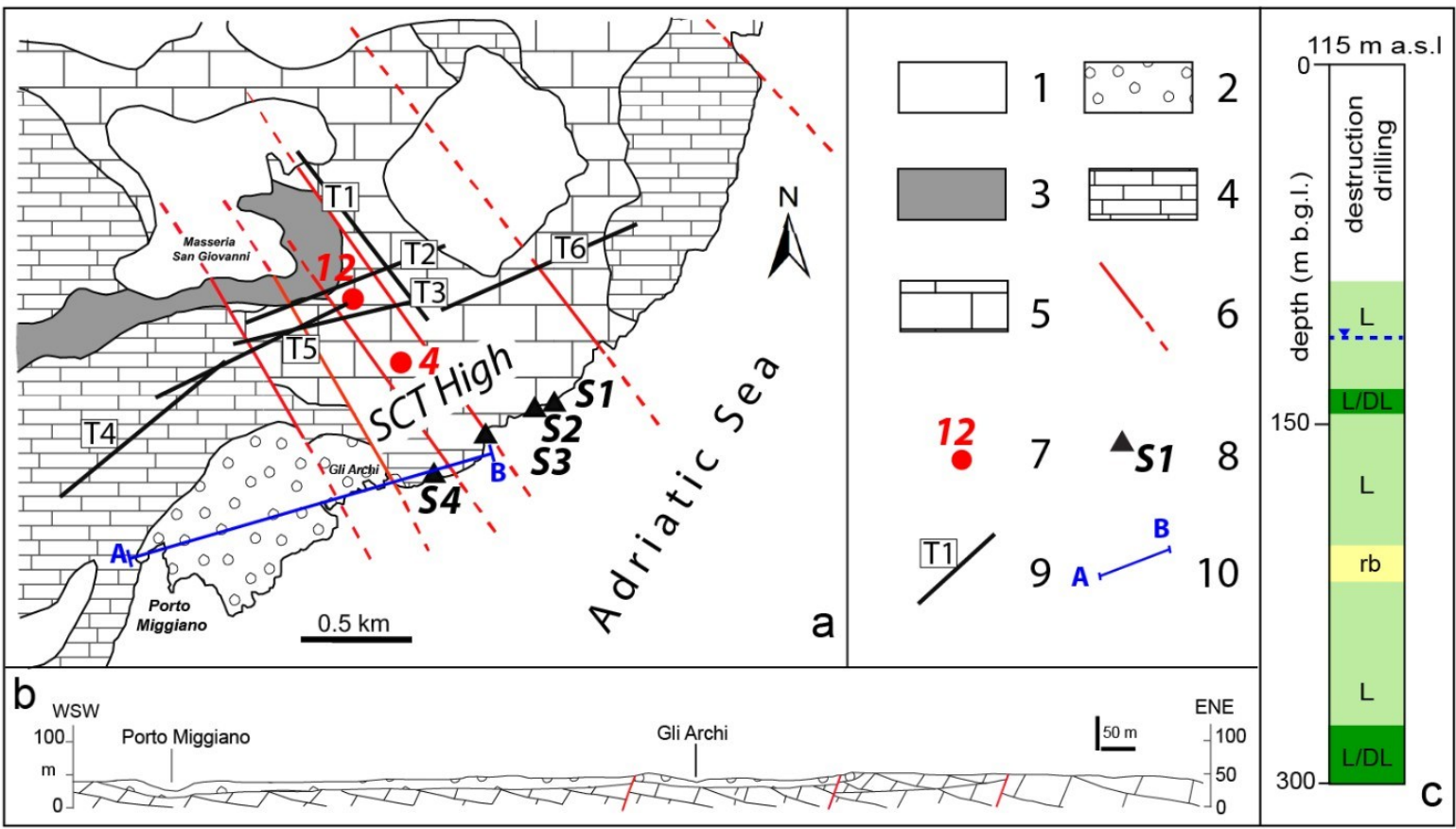

Figure 1. a) Simplified geological map. Legend: 1) red clays, 2) Salento Calcarenites, 3) Porto Badisco Calcarenites, 4) Castro Limestone, 5) Altamura Limestone, 6) fault (atranstensional, b-normal, dashed when inferred), 7) borehole 12, 8) thermal spring, 9) total Electrical Resistivity Tomography (ERT) data profile, 10) trace of the geological section; b) geological section; c) stratigraphic column of borehole 4. Legend: $\mathrm{L}=$ Limestone, $\mathrm{L} / \mathrm{DL}=$ Limestone and dolomitic limestone, $\mathbf{r b}=$ Microcrystalline limestone with traces of macrofossils.

\section{RESULTS}

The Figure 2 shows the total ERT profile obtained from the elaboration of the apparent electrical resistivity data coming from the profiles T3, T4, T5 and T6 in figure 1. Along the profile two empty data are well showed (white triangle), due to a lack of an overlap of the performed measurement. In general, the ERT image shows high electrical resistivity values $\left(>500 \mathrm{Ohm}^{*} \mathrm{~m}\right)$. In details, the ERT image highlights two electrical resistivity distribution zones: the western one, from the starting point to around $1000 \mathrm{~m}$, and the eastern one, from $1000 \mathrm{~m}$ to the end of the profile. The western zone shows a heterogeneity resistivity distribution with lateral and vertical variation. In details, between $700 \mathrm{~m}$ to $1000 \mathrm{~m}$ some vertical high electrical resistivity structures were recognized, while the first part of the profile shows horizontal electrical resistivity layers with low values $(<500 \mathrm{Ohm} * \mathrm{~m})$. 


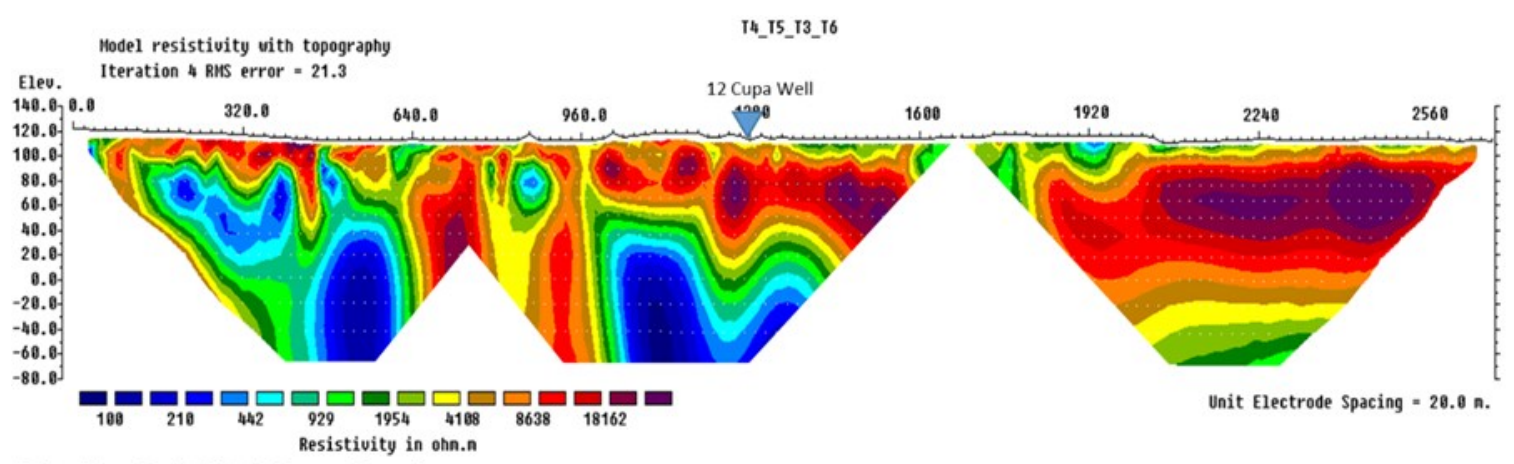

Figure 2. The total GRT profile inverted from the T4, T5, T3, and T6 data profile. The position of the GRTs profile is showed on Figure 1.

The eastern electrical resistivity zone displays a horizontal layer $(>2000 \mathrm{Ohm} * \mathrm{~m})$ that increases in thickness going to the East (from $20 \mathrm{~m}$ to $-80 \mathrm{~m}$ asl); below this layer, between $1000 \mathrm{~m}$ to around $1500 \mathrm{~m}$ a relative low resistivity layer $(<400 \mathrm{Ohm} * \mathrm{~m})$ is well defined.

\section{DISCUSSION AND CONCLUSIONS}

The complex electrical resistivity distribution could be interpreted from the geological point of view combining the geological knowledge of the area with the hydrogeological conceptualization. The geological formations (calcareous rocks) present in the area have very similar electrical characteristics (high resistivity values). However, the presence of some elements of erosion or fracturing and porosity variation due to the fault system assumes an important effect on the electrical resistivity heterogeneity. Therefore, some relatively lower resistivity values of the rocks are well defined, at least for the superficial parts on the western investigated zone, that should be associated to filled karst structures. Furthermore, in depth, their variability may depend on the presence of water circulations with salt characteristics and/or higher temperatures, as described by Archie's law. The thermal well (12, Cupa Well) shows thermal water at $0 \mathrm{~m}$ a.s.1., therefore the presence of a saline or heat fluid safely affects the resistivity distribution (i.e. water with high salt content or a high temperature produces a lowering of the resistivity values). Finally, the strong lateral variation (vertical structures) should be associated to the main fault system which delimited the deep geothermal zone well, as hypothesized on the basis of some well data.

\section{REFERENCES}

Abate, S., Aldighieri, B., Ardizzone, F., Barnaba, F., Basso, A., Botteghi, S., Caielli, G., Calvi, E., Caputi, A., Caputo, M. C., Cardellicchio, N., De Carlo, L., Casarano, D., Desiderio, G., De Franco, R., De Leo, M., Donato, A., Dragone, V., Festa, V., Giocoli, A., Inversi, B., Limoni, P.P, Liotta D., Lollino, P., Lombardo, G., Manzella, A., Masciale, R., Minissale, M., Montanari, D., Montegrossi, G., Mussi, M., Pagliarulo, R., Palladino, G., Parise, M., Perrone, A., Petrullo, A., Piemonte, C., Piscitelli S., Polemiol, M., Rizzo, E., Romanazzi, A., Romano ,G., Santaloia, F., Scrocca, D., Wasowski, J., and Zuffianò, L.E. 2015. VIGOR: Sviluppo geotermico nella regione Puglia - Studi di Fattibilità a Bari e Santa Cesarea Terme. Progetto VIGOR - Valutazione del Potenziale Geotermico delle Regioni della Convergenza, POI Energie Rinnovabili e Risparmio Energetico 2007-2013, CNRIGG, ISBN: 9788879580168. www.vigor-geotermia.it 
Aiello, G. and Budillon, F. 2004. Lowstand prograding wedges as 4th order glacio-eustatic cycles in the Pleistocene continental shelf of Apulia. SEPM Special Publication n. 81, Cyclostratigraphy: Approaches and Case Histories, ed. D'Argenio B et al., 215-230.

Bosellini, A., Bosellini, F.R., Colalongo, M. L., Parente, M., Russo, A. and Vescogni, A. 1999. Stratigraphic architecture of the Salento coast from Capo d'Otranto to Santa Maria di Leuca (Apulia, southern Italy). Riv. Ital. Paleont. Strat., 105 (3): 397-416.

Bossio, A., Mazzei, R., Monteforti, B. and Salvatorini, G. 2005. Stratigrafia del Neogene e Quaternario del Salento sud-orientale (con rilevamento geologico alla scala 1:25.000). Geologica Romana, 38: $31-60$.

Caputo, R., Piscitelli, S., Oliveto, A., Rizzo, E., Lapenna, V. 2003. High-resolution resistivity tomographies in active tectonic studies. Examples from the Tyrnavos Basin, Greece. Journal of Geodynamics 36: 19-35.

De Giorgio, G., Chieco, M., Zuffianò, L.E., Limoni, P.P., Sottani, A., Pedron, R., Vettorello, L., Stellato, L., Di Rienzo, B., Polemio, M. 2018. The Compatibility of Geothermal Power Plants with Groundwater Dependent Ecosystems: The Case of the Cesine Wetland (Southern Italy). Sustainability, 10, 303.

Lapenna, V., Lorenzo, P., Perrone, A., Piscitelli, S., Rizzo, E., Sdao, F. 2003. High-resolution geoelectrical tomographies in the study of the Giarrossa landslide (Potenza, Basilicata). Bull. Eng. Geol. Environ. 62: 259-268.

Loke, M.H. 2001. Tutorial: 2-D and 3-D electrical imaging surveys. I: Course notes for USGS workshop 2-D and 3-D inversion and modelling of surface and borehole resistivity data. Storrs, CT, pp. 13-16.

Loke, M.H. and Barker, R.D., 1996. Rapid least-squares inversion of apparent resistivity pseudosections by a quasi-Newton method. Geophysical Prospecting, 44; 131-152.

Perrone, A., Iannuzzi, A., Lapenna, V., Lorenzo, P., Piscitelli, S., Rizzo, E., Sdao, F. 2004. Highresolution electrical imaging of the Varco d'Izzo earth flow (southern Italy). J. Appl. Geophys. 56: 17 -29 .

Ricchetti, G., Ciaranfi, N., Luperto Sinni, E., Mongelli, F. and Pieri, P. 1988. Geodinamica ed evoluzione sedimentaria e tettonica dell'Avampaese Apulo. Memorie della Società Geologica Italiana, 41: 57-82.

Romanazzi, A., Gentile, F., Polemio, M. 2015. Modelling and management of a Mediterranean karstic coastal aquifer under the effects of seawater intrusion and climate change. Environ Earth Sci $74 ; 115-128$.

Santaloia, F., Zuffianò, L. E., Palladino, G., Limoni, P. P., Liotta, D., Minissale, A., Brogi, A. and Polemio, M. 2016. Coastal thermal springs in a foreland setting: The Santa Cesarea Terme system (Italy). Geothermics 64: 344-361.

Tozzi, M. 1993. Assetto tettonico dell'avampaese apulo meridionale (Murge meridionali-Salento) sulla base dei dati strutturali. Geologica Romana, 29: 95 - 111.

Contact Information: Maurizio Polemio, Consiglio Nazionale delle Ricerche, Research Institute for Hydrogeological Protection (CNR-IRPI), Via Amendola 122 I, 70126 Bari, Italy, Phone: +39-0805929584, Email: m.polemio@ba.irpi.cnr.it 